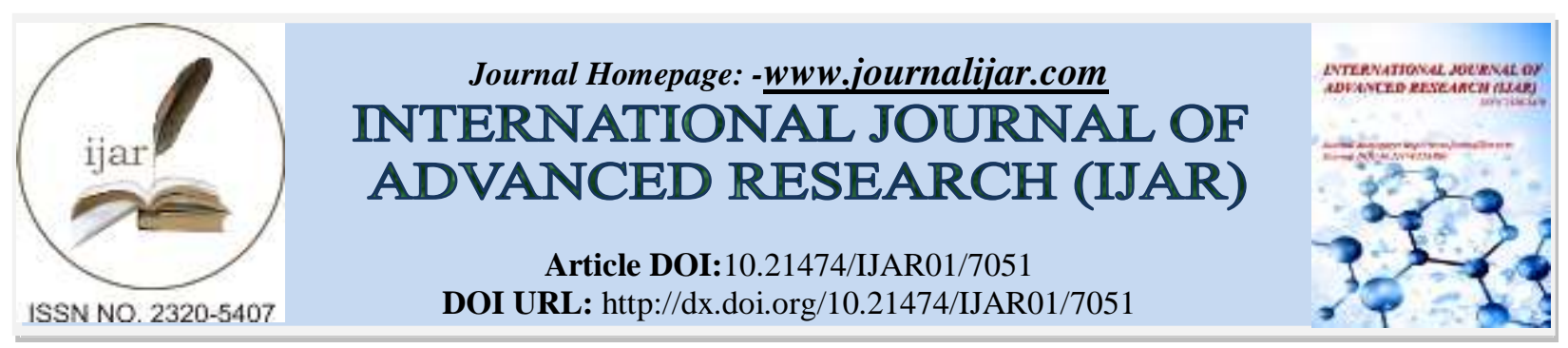

RESEARCH ARTICLE

\title{
SHELF LIFE IMPROVEMENT OF FOOD PRODUCTS ON EXPOSURE TO GAMMA-RADIATION.
}

\section{Bindu ${ }^{1}$, Dr. D. Sarada ${ }^{2}$ and Dr. S. Vijaya Jyothi ${ }^{3}$.}

1. Assistant Professor, Department of Home Science, Sri Padmavati Mahila VisvaVidyalayam (Women's University), Tirupati, Andhra Pradesh, India.

2. Professor, Department of Home Science, Sri Padmavati Mahila VisvaVidyalayam (Women's University), Tirupati, Andhra Pradesh, India.

3. Associate Professor, Department of Home Science, Sri Padmavati Mahila VisvaVidyalayam (Women's University),Tirupati, Andhra Pradesh, India.

\section{Manuscript Info}

\section{Manuscript History}

Received: 07 March 2018

Final Accepted: 09 April 2018

Published: May 2018

Keywords:-

Irradiation, Gamma radiation, Shelf Life, Health mixes, Nutritional quality.

\begin{abstract}
Ionizing radiation was first recognized with the discovery of $\mathrm{x}$-rays. Within a year of its discovery, it was suggested as a means to kill microorganisms in food. Gamma rays also with specific energies come from the spontaneous disintegration. Only certain radiation sources can be used for food irradiation, because all do not penetrate into foods. These ionizing radiation passes through food without generating intense heat (as infrared and microwave radiation do) while disrupting the cellular processes associated with sprouting, ripening or growth of microorganisms, parasites and insects by instituting or stopping them. The processing is normally done at low temperature and under modified atmospheres to avoid adverse effects on the sensory quality of the product. The effect of gamma irradiation at two irradiation doses ( 0.25 and $0.75 \mathrm{kGy})$ was observed on health mixes-I\&II. It was reported that at low doses of radiation levels there were no changes in Nutritional quality of foods occurs, hence it was proposed to study two levels of low dose radiation $(0.25 \mathrm{kGy}$ and $0.75 \mathrm{KGy}$ for the developed Health Mixes.The shelf life of Non-irradiated and Irradiated Health Mixes-I and II were tested by analysing their Microbial assays I and II. Thus our current study we had focused on Gamma irradiation on Health mix products, which has been significantly suggested to inhibit microbial growth and extend the shelf life of Health mixes-I\&II.
\end{abstract}

Copy Right, IJAR, 2018,. All rights reserved.

Introduction:-

In 1980 a joint FAO/IAEA/WHO Expert Committee on Food Irradiation (JECFI) reviewed the extensive data on wholesomeness collected upto that time and concluded that irradiation of any commodity upto an overall dose of $10 \mathrm{kGy}$ presents no toxicological hazards and introduces no special nutritional or microbiological problems. An Expert Group constituted by WHO in 1994 once again reviewed the wholesomeness data available till then and validated the early conclusion of JECFI. Food irradiation is approved for use in over 60 countries worldwide for different products, such as grains, herbs and spices, poultry, seafood, and ground beef (Kume et al., 2009). Irradiation does not cause any significant loss of macronutrients. 
FDA approved the first use of Irradiation on a food product in 1963 when it allowed Irradiation treated wheat and wheat flour to be marketed. In approving, the use of radiation, FDA sets the maximum radiation dose. The product can be exposed to, measured in Kilo Gray (kGy). FDA, 1997 proposed that Irradiation can help to control the potentially harmful bacteria salmonella and campylobacter two chief causes of food-borne illness. It was estimated that Salmonella commonly found in poultry, eggs, meat and milk sickness as many as 4million and kills 1,000 per year nationwide. FDA officials emphasize that though Irradiation is a useful tool for reducing food-borne disease risks. It complements but doesn't replace proper handling, practices by producers, processors and consumers.

Jozsef Farkas, (1990) opined that when foods are exposed to ionizing radiation under conditions envisioned for commercial application, no significant impairment in the nutritional quality of protein, lipid and carbohydrate constituents was observed. Irradiation was no more destructive to vitamins than other food preservation methods. Protection of nutrients is improved by holding the food at low temperature during irradiation and by reducing or excluding free oxygen from the radiation milieu. In the case of fungi, heat treatment preceding irradiation usually results in a greater antimicrobial effect of the combination process compared with heating after irradiation (Ahari et al., 2011). The usefulness of mild heat treatment prior to low-dose irradiation has been demonstrated for extending the shelf-life of certain fruits and cereal products, preservation of fruit juices and some other processed fruit products, and for inactivation of toxigenic moulds on nuts, dried fruits, cocoa beans and maize. With bacterial spores, pre-irradiation followed by heating proved to be synergistic. This combination may be utilized for preservation of foods where heat resistance of bacterial spores is a critical factor. The radiation-damaged bacterial spores in irradiated dry food ingredients have been shown to be more easily destroyed by normal heat processing of complex foods containing such ingredients. In specific cases simultaneous application of heat and radiation (thermo-radiation) might be considered for an enhanced destruction of microbes. Thermal stress can also complement or potentiate the effectiveness of radiation disinfestations.

Anurag Chaturvedi (2013) studied and reported that freshly harvested grains contain loads of thousand to million bacteria and mould spore per gram and the microbial contribution of cereal grains and flours to convenience foods is an important consideration from public health aspects and as a source of possible spoilage agents. Although the microbial load of cereal grains, meals, and flours may not constitute a spoilage problem by itself, the numbers and types of microorganisms in such products is of concern since these products are used in the formation of many other foods. Radiation processing technology can be used for disinfestations of food grains and certain pre-packed cereal products like atta (flour), suji (semolina) and premixes. The present study was conducted to establish radiation processing protocols to improve the shelf life with optimum retention of quality of selected grains namely ragi and barley. Grain samples were taken in triplicates in a polythene bag (100 gauge) of 500gms each, heat sealed and subject to radiation doses $0.25,0.50,0.75$ and $1.00 \mathrm{kGy}$ using Gamma chamber and stored for a period of one year. Grains were assessed for Moisture, Total Bacterial Count (TBC) and Total Mould Count (TMC), Diastase activity and for organoleptic attributes.

Ionizing radiation is an economically viable technology for reducing postharvest losses, extending shelf life of perishable commodities and maintaining hygienic quality of fresh produce (Gonzalez-Aguilar G et al., 2004; Xiong et al., 2009 and Fan et al., 2012). Studies have shown that irradiation increases the shelf life of various tropical and subtropical fruits such as papayas, mangoes and bananas (Thomas et al., 1979; Akamine et al., 1983 and Dinnocenzo et al., 2001) and also leads to the inactivation of microorganisms (Zhang et al., 2006; Cia et al., 2007 and Olanya et al., 2015). Irradiation has been proved to inhibit microbial growth, delay ripening and extend the shelf life of fruits and vegetables.

However, the data on the use of gamma irradiation to prolong the shelf life and microbiological quality of health mixes-I\&II are limited. The present investigation was undertaken to evaluate the effectiveness of gamma radiation on extending the shelf life of Health mixes. The objective of the study was to optimize the irradiation dose for the shelf life extension and to investigate the impact of gamma irradiation on physico-chemical, microbiological and sensory qualities of products. Irradiation is emerging as a potential method of food preservation. It is being used to extend the shelf life of raw and processed foods in many countries worldwide.

\section{Materials and Methods:-}

\section{Selection of Health Mixes:-}

For the present study the ingredients selected includes Ragi (Eleusine Coracana), Wheat (Triticum Aestivum), Rice flakes (Oryzasativa), Bengal gram (Cicer Arietinum), Green gram whole (Phaseolus Aureus Roxb), Black gram 
(Phaseolus Mungo Roxb), Horse gram (Dolichos Biflorus), Cowpea (Vigna Catjang), Soya (Glycine Maxnerr), and Sesame seeds (Sesamum Indium) were procured from local market in Tirupati, Andhra Pradesh.

\section{Irradiation of Health Mixes I and II:-}

It was reported that at low doses of radiation levels there were no changes in Nutritional quality of foods occurs, hence it was proposed to study two levels of low dose radiation $(0.25 \mathrm{kGy}$ and $0.75 \mathrm{KGy}$ for the developed Health Mixes I and II.

Two samples of each health mix (500g) was weighed and packed in Polythene pouches and sealed, all the samples were labeled appropriately and were stored at room temperature until the time of irradiation. The irradiation process was carried out in Gamma ( $($ ) radiation chamber in irradiation unit at PJSR Agricultural University, Hyderabad, India. For the irradiation of samples, Cobalt-60 was used as a radioactive compound.

\section{Quality Attributes:-}

Titratable Rancidity and pH Titratable Rancidity was determined according to the AOAC methods. Health mixes-I and Health Mixes-II was prepared and the $\mathrm{pH}$ and Rancidity was determined.

\section{Sensory Evaluation:-}

Sensory attributes namely colour, texture, and overall acceptability were evaluated on a five point scale. Sensory testing was performed by panel lists and numerical values were assigned to each attribute on a Hedonic 5-point scale.

\section{Microbial Analysis:-}

\section{Dilution plate technique:-}

The dilution plate count is the most frequently used technique for determining the number of viable microbial in samples. The technique is based upon the assumption that when a known weight of the sample is agitated in the suitable liquid, the microorganisms before detached from the sample and each of the detached cells gives rise to discrete colony when plate on a nutrient medium in a Petri dish. These colonies are counted and the number of cells in the original sample estimated since the number of cells even in a small sample is large. The suspension of cells must be diluted so that a small number of well separated colonies develop on each Petri dish.

The variation 1 of Health Mixes I and variation 1 of Health Mixes II were selected for production and supplementation to the selected sample. The shelf life of both the Health Mixes Non- Irradiation and irradiated were evaluated after 15 days, 30 days and 120 days. The Health Mixes were stored at room temperature. Plates with CFUs were utilized to calculate the CFU/100g. The CFUs reported reflect the average of 4 plates.

\section{Statistical Analysis:-}

All statistical analysis was done in triplicate and average values are calculated. Data were presented as mean \pm Standard Deviation. The results were statistically analysed by one way analysis of variance and means were compared using bonferroni post hoc test with least significant differences procedure at 0.05 levels were used to describe the significance of differences between control and irradiated samples. Graph pad prism 3.1 version was used as statistical analysis software.

\section{Results and Discussion:-}

\section{Effect of Gamma radiation on shelf life:-}

The shelf life of Non-irradiated and Irradiated Health Mixes I and II were tested by analysing their Microbial assay.

The results of Microbiological analysis of Health Mixes-I and II were presented and discussed in table-1\&2.

Table 1:-pH and Rancidity of the Health Mixes I

\begin{tabular}{|c|c|c|c|c|c|c|c|}
\hline \multirow{3}{*}{$\begin{array}{l}\text { S. } \\
\text { No }\end{array}$} & \multirow[t]{3}{*}{ Sample } & \multicolumn{6}{|c|}{ pH and Rancidity of the Health Mixes I } \\
\hline & & \multicolumn{3}{|c|}{ pH } & \multicolumn{3}{|c|}{ Rancidity } \\
\hline & & $\begin{array}{c}\text { Non- } \\
\text { Irradiated }\end{array}$ & $\begin{array}{l}\text { Irradiated } \\
@ 0.25 \mathrm{kGy}\end{array}$ & $\begin{array}{l}\text { Irradiated } \\
@ 0.75 \mathrm{kGy}\end{array}$ & $\begin{array}{c}\text { Non- } \\
\text { Irradiated }\end{array}$ & $\begin{array}{l}\text { Irradiated } \\
@ 0.25 \mathrm{kGy}\end{array}$ & $\begin{array}{l}\text { Irradiated } \\
@ 0.75 \mathrm{kGy}\end{array}$ \\
\hline 1. & Fresh & 7.2 & 7.2 & 7.4 & 0.28 & 0.20 & 0.22 \\
\hline
\end{tabular}




\begin{tabular}{|c|l|c|c|c|c|c|c|}
\hline & \multicolumn{2}{|l|}{ sample } & & & & & \\
\hline 2. & $\begin{array}{l}15 \text { days } \\
\text { old }\end{array}$ & 6.4 & 6.8 & 7.2 & 0.31 & 0.29 & 0.24 \\
\hline 3. & $\begin{array}{l}30 \text { days } \\
\text { old }\end{array}$ & 6.0 & 6.2 & 6.4 & 0.46 & 0.34 & 0.31 \\
\hline 4. & $\begin{array}{l}120 \text { days } \\
\text { old }\end{array}$ & 4.0 & 5.4 & 6.0 & 1.68 & 1.02 & 0.68 \\
\hline
\end{tabular}

Table 2:-pH and Rancidity of the Health Mixes II

\begin{tabular}{|c|c|c|c|c|c|c|c|}
\hline \multirow{3}{*}{$\begin{array}{l}\text { S. } \\
\text { NO }\end{array}$} & \multirow[t]{3}{*}{ Sample } & \multicolumn{6}{|c|}{ pH and Rancidity of the Health Mixes II } \\
\hline & & \multicolumn{3}{|c|}{ pH } & \multicolumn{3}{|c|}{ Rancidity } \\
\hline & & $\begin{array}{c}\text { Non- } \\
\text { Irradiated }\end{array}$ & $\begin{array}{l}\text { Irradiated } \\
@ 0.25 \mathrm{kGy}\end{array}$ & $\begin{array}{l}\text { Irradiated } \\
@ 0.75 \mathrm{kGy}\end{array}$ & $\begin{array}{c}\text { Non- } \\
\text { Irradiated }\end{array}$ & $\begin{array}{l}\text { Irradiated } \\
@ 0.25 \mathrm{kGy}\end{array}$ & $\begin{array}{l}\text { Irradiated } \\
@ 0.75 \mathrm{kGy}\end{array}$ \\
\hline 1. & $\begin{array}{c}\text { Fresh } \\
\text { sample }\end{array}$ & 7.0 & 7.2 & 7.4 & 0.28 & 0.20 & 0.22 \\
\hline 2. & $\begin{array}{c}15 \text { days } \\
\text { old }\end{array}$ & 6.4 & 6.8 & 7.2 & 0.31 & 0.29 & 0.24 \\
\hline 3. & $\begin{array}{c}30 \text { days } \\
\text { old }\end{array}$ & 6.0 & 6.2 & 6.4 & 0.46 & 0.38 & 0.31 \\
\hline 4. & $\begin{array}{c}120 \text { days } \\
\text { old }\end{array}$ & 4.2 & 5.8 & 6.2 & 1.68 & 1.32 & 1.02 \\
\hline
\end{tabular}

The table 1 and 2 show the $\mathrm{pH}$ and rancidity of the Health Mixes-I (for Diabetics) and Health Mixes-II (Adolescent girls). The results in the table 1 and 2 showed that the $\mathrm{pH}$ of the samples decreased as the Shelf life increased both for the non-Irradiated and Irradiated samples. The $\mathrm{pH}$ of the Health Mixes-I and II samples Irradiated at $0.75 \mathrm{kGy}$ indicated that the shelf life is not poor as the $\mathrm{pH}$ was 6.0 to 6.2 and gamma -radiation was useful in presentation of Health Mixes as they improve the shelf life of the products with regard to the rancidity in the Health Mixes I and II, the levels of rancidity is more in non-irradiated health mixes than the irradiated samples. The rancidity levels were slightly more in Irradiated samples of Health Mixes- II than Health Mixes-I, this may be due to the presence of powdered gingerly seeds in Health Mix II. This result reveals that the gamma- radiation has an effect on rancidity of the food products also.

The Shelf life of Health Mixes (Variation-1) and Health Mixes-II (Variation-2) was assessed by microbiological analysis, $\mathrm{pH}$ and rancidity. The microbial growth in the Fresh Health mixes and preserved (for 15 to 120 days). Health Mixes were examined for number of colonies formed on the Agar plate. The Non-Irradiated sample that is the fresh sample at $24 \mathrm{hrs}$ exposure resulted in $4 \times 10^{3} \mathrm{CFU} / \mathrm{g}$ and when irradiated with $0.25 \mathrm{kGy}$ and $0.75 \mathrm{kGy}$ the CFU/g in fresh sample was $1 \times 10^{3}$ but in 15 days, 30 days \& 120 days old sample the CFU/g was shown in figure and table-3 and 4, Which clearly signifies that samples when exposed to $0.25 \mathrm{kGy}$ showed decrease in CFU/g. when compared with fresh sample but more significant decreased observed in $0.75 \mathrm{kGy}$ product. When samples were incubated at 48 hours the Non- Irradiated product showed in figure \& table was compared with two doses whereas, comparatively the 0.25 showed decrease in CFU/g and as well much reduction was observed with 0.75 in 120 days

Table 3:-Microbiological analysis of Health Mix I (Non- Irradiated and Irradiated)

\begin{tabular}{|c|c|c|c|c|c|c|c|}
\hline \multirow{3}{*}{$\begin{array}{l}\text { S. } \\
\text { NO }\end{array}$} & \multirow[t]{3}{*}{ Sample } & \multicolumn{6}{|c|}{ Microbial growth } \\
\hline & & \multicolumn{3}{|c|}{24 hours of incubation (CFU/g) } & \multicolumn{3}{|c|}{48 hours of incubation(CFU/g) } \\
\hline & & $\begin{array}{c}\text { Non- } \\
\text { Irradiated }\end{array}$ & $\begin{array}{l}\text { Irradiated } \\
@ 0.25 \mathrm{kGy}\end{array}$ & $\begin{array}{l}\text { Irradiated } \\
@ 0.75 \mathrm{kGy}\end{array}$ & $\begin{array}{c}\text { Non- } \\
\text { Irradiated }\end{array}$ & $\begin{array}{l}\text { Irradiated } \\
@ 0.25 \mathrm{kGy}\end{array}$ & $\begin{array}{l}\text { Irradiated } \\
@ 0.75 \mathrm{kGy}\end{array}$ \\
\hline 1. & Fresh sample & $4 \times 10^{3}$ & $1 \times 10^{3}$ & $0.7 \times 10^{3}$ & $5 \times 10^{3}$ & $2 \times 10^{3}$ & $1 \times 10^{3}$ \\
\hline 2. & 15 days old & $6 \times 10^{3}$ & $2 \times 10^{3}$ & $1.4 \times 10^{3}$ & $8 \times 10^{3}$ & $4 \times 10^{3}$ & $2 \times 10^{3}$ \\
\hline 3. & 30 days old & $25 \times 10^{3}$ & $1.0 \times 10^{3}$ & 0.8 & $30 \times 10^{3}$ & $1.6 \times 10^{3}$ & $1.2 \times 10^{3}$ \\
\hline 4. & 120 days old & $36 \times 10^{3}$ & $0.6 \times 10^{3}$ & $0.5 \times 10^{3}$ & $40 \times 10^{3}$ & $0.8 \times 10^{3}$ & $0.7 \times 10^{3}$ \\
\hline
\end{tabular}

Table 4:-Microbiological analysis of Health Mix II (Non- Irradiated and Irradiated)

\begin{tabular}{|c|c|c|c|}
\hline S. & Sample & \multicolumn{2}{|c|}{ Microbial growth } \\
\cline { 3 - 4 } NO & & 24 hours of incubation(CFU/g) & 48 hours of incubation(CFU/g) \\
\hline
\end{tabular}




\begin{tabular}{|c|c|c|c|c|c|c|c|}
\hline & & $\begin{array}{c}\text { Non- } \\
\text { Irradiated }\end{array}$ & $\begin{array}{c}\text { Irradiated } \\
\text { @ 0.25kGy }\end{array}$ & $\begin{array}{c}\text { Irradiated } \\
\text { @ 0.75kGy }\end{array}$ & $\begin{array}{c}\text { Non- } \\
\text { Irradiated }\end{array}$ & $\begin{array}{c}\text { Irradiated } \\
\text { @ 0.25kGy }\end{array}$ & $\begin{array}{c}\text { Irradiated } \\
@ \mathbf{0 . 7 5 k G y}\end{array}$ \\
\hline 1. & Fresh sample & $4 \times 10^{3}$ & $1 \times 10^{3}$ & $0.7 \times 10^{3}$ & $6 \times 10^{3}$ & $2 \times 10^{3}$ & $1 \times 10^{3}$ \\
\hline 2. & 15 days old & $8 \times 10^{3}$ & $3 \times 10^{3}$ & $2 \times 10^{3}$ & $1.8 \times 10^{3}$ & $4 \times 10^{3}$ & $2 \times 10^{3}$ \\
\hline 3. & 30 days old & $25 \times 10^{3}$ & $2 \times 10^{3}$ & $1 \times 10^{3}$ & $0.9 \times 10^{3}$ & $3 \times 10^{3}$ & $1.2 \times 10^{3}$ \\
\hline 4. & 120 days old & $36 \times 10^{3}$ & $0.6 \times 10^{3}$ & $0.5 \times 10^{3}$ & $0.4 \times 10^{3}$ & $0.8 \times 10^{3}$ & $0.7 \times 10^{3}$ \\
\hline
\end{tabular}

The results of Micro biological analysis indicates that the Irradiated Health Mix I and II had lower CFU/g of the sample, when compared to Non- Irradiated samples of Health Mix I and II. Which reveals that the $\gamma$-radiation at doses of $0.25 \mathrm{KGy}$ and $0.75 \mathrm{kGy}$ were effective in improving the shelf life of the Health mixes I and II.

\section{Sensory Evaluation for Non Irradiated and Irradiated Health Mix-I:-}

The Variation (V1) of Health Mix-I was subjected to Gamma irradiation at low doses $0.25 \mathrm{kGy}$ and $0.75 \mathrm{kGy}$ in quantities of $500 \mathrm{~g}$ each. With the two samples irradiated of Health Mix-I, Rotis (25g/Roti) were prepared and subjected to sensory evaluation with the help of same panel members. The Panel members were informed about the irradiation and the consent was taken prior to the selection of panel. The mean sensory evaluation scores of rotis prepared with irradiated Health mix-I was presented in Table 5.

Table 5:-Comparison of the Mean Sensory Evaluation scores of irradiated and Non irradiated Health mix - I $\left(\mathrm{V}_{1}\right)$

\begin{tabular}{|c|l|c|c|c|}
\hline \multirow{2}{*}{ S.No } & \multicolumn{1}{|c|}{$\begin{array}{c}\text { Sensory evaluation } \\
\text { attributes }\end{array}$} & Non Irradiated Health Mix-I & \multicolumn{2}{|c|}{ Mean Scores of Health Mix-I } \\
\cline { 4 - 5 } & \multicolumn{2}{|c|}{$\begin{array}{c}\text { @ 0.25kGy } \\
\text { @ 0.75kGy }\end{array}$} \\
\hline 1 & Appearance & 4.3 & 4.2 & 4.2 \\
\hline 2 & Texture & 4.4 & 4.2 & 4.1 \\
\hline 3 & Taste & 4.2 & 4.2 & 4.1 \\
\hline 4 & Flavour & 4.4 & $4-1$ & $4-1$ \\
\hline 5 & Overall acceptability & 4.3 & 4.1 & 4.1 \\
\hline
\end{tabular}

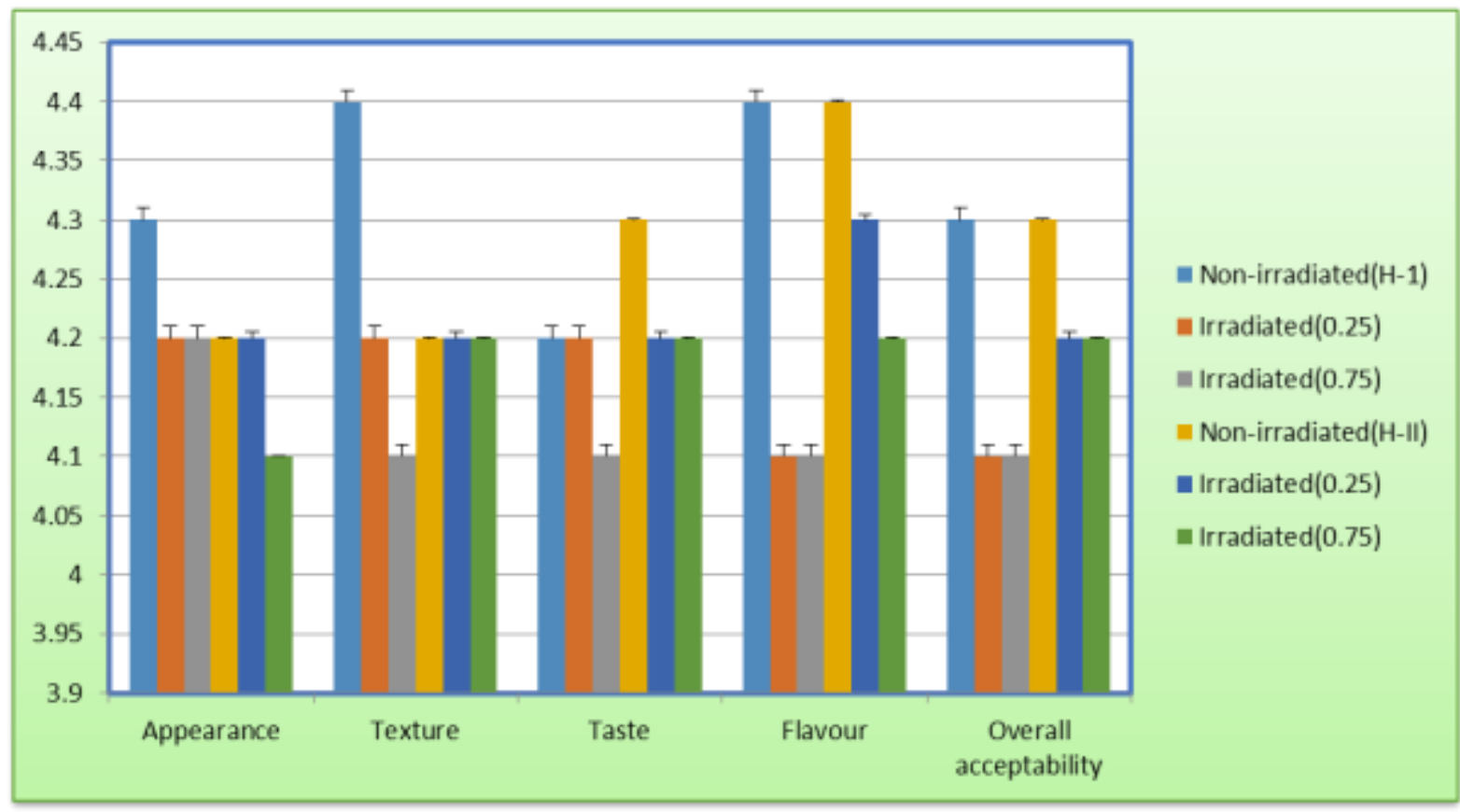

Figure 1:-Sensory evaluation scores of irradiated and non-irradiated health mix-I and Health mix-II Comparison of the mean scores for sensory evaluation of irradiated and non-irradiated Health Mix II 
Table 6:-Comparison of the mean scores for sensory evaluation of irradiated and non-irradiated Health Mix II

\begin{tabular}{|c|l|c|c|c|}
\hline S.No & Sensory evaluation & \multirow{2}{*}{$\begin{array}{c}\text { Non Irradiated } \\
\text { attributes }\end{array}$} & Health Mix-II & \multicolumn{2}{|c|}{\begin{tabular}{c} 
Irradiated Health Mix-II \\
\cline { 3 - 4 }
\end{tabular}} & & $\begin{array}{c}\text { Variation 1 } \\
\text { Mean Score }\end{array}$ & Variation2 Mean score \\
\hline 1 & Appearance & 4.2 & 4.2 & 4.1 \\
\hline 2 & Texture & 4.2 & 4.2 & 4.2 \\
\hline 3 & Taste & 4.3 & 4.2 & 4.2 \\
\hline 4 & Flavour & 4.4 & 4.3 & 4.2 \\
\hline 5 & Overall acceptability & 4.3 & 4.2 & 4.2 \\
\hline
\end{tabular}

Table 6: shows the mean sensory evaluation scores of two variations: V1 and V2 of Health Mix II. From the data it was clear that the variation one had slightly higher scores for all the attributes than the variation 2 . The means scores for both the variations were between 4 to 5 indicating that both the products were very good. Based on the sensory evaluations means scores the variation1 of Health Mix II was selected for irradiation, nutritional quality assessment and nutritional intervention to adolescent girls.

Table-6 indicates that there was negligible difference among the mean sensory evaluation scores of non-irradiated (at two doses) Health Mix II for 5 attributes. This reveals that there is not much difference among the irradiated and non-irradiated Health Mix II products. Further sensory evaluation mean scores were between 4 to 5 for all the attributes indicating they were rated as very good by panel members by 5 point hedonic scales.

\section{Conclusion:-}

The study on Nutritional and Biochemical Investigations of Radiation Processed foods conducted by developing Health Mixes -I and II for diabetic women and adolescent girls were accepted and rated as very good. The Irradiated Health Mixes -I and II did not differ much in their nutritional quality from the non-irradiated samples indicating that the gamma irradiation at doses $0.25 \mathrm{kGy}$ and $0.75 \mathrm{kGy}$ did not alter the nutrient values of Health mixes. The shelf life of the Health Mixes -I and II showed that the CFU/g of the irradiated samples differed between two doses and also from non-irradiated samples. Which indicates that irradiation controlled or lowered the microbial levels in Health Mixes. The $\mathrm{pH}$ and the rancidity in the non-irradiated and irradiated samples showed that the $\mathrm{pH}$ levels lowered over storage and rancidity increased. Indicating that the irradiated and non-irradiated samples differed in their $\mathrm{pH}$ and rancidity levels indicating that the irradiation has helped in lowering the rancidity levels and influencing the $\mathrm{pH}$.

\section{Acknowledgements:-}

The authors express their appreciation to Sri Padmavathi Mahila Visvavidyalayam (Women's) University for providing access to the research facilities and for actively participating in the study and also thanks to the faculty, staff, and students from the Mahila University for their assistance in the research studies. The authors are also highly thankful to PJSR Agricultural University, Hyderabad, India, for assisting and guiding in Irradiation product work and I acknowledge Dr.K.R.Padma for her statistical data and Prof.D.Sarada for her eminent guidance and timely help.

\section{References:-}

1. Anurag Chaturvedi, TVN Padmavathy, J Dilip Babu1 and AK Sharma (2013) Effect of radiation on nutritional quality, shelf life and and acceptability of Ragi (Eleusine coracana) and Barley (Hordeum vulgare) Advances in Applied Science Research, 2013, 4(4):11-16 Pelagia Research Library ISSN: 0976-8610 CODEN (USA): AASRFC

2. Ahari, M. H; Mirmajlessi, S. M; Fathollahi, H.; Minasyan, V. \& Mirjalil S. M. (2011). Evaluation of gamma irradiation effect and Pseudomonas flourescens against Penicillium expansum, African J. Biotech., Vol. 10, no. 54, pp. 11290-11293.

3. AOAC, 2005. Official Methods of Analysis (18th edn.). Association of Official Analytical Chemists. Washington. DC.

4. Kume, T.; Furuta, M.; Todoriki, S.; Uenoyama, N. \& Kobayashi, Y. (2009). Status of food irradiation in the world, Radiation Physics and Chemistry, Vol. 78, no. 3, pp. 222-226.

5. WHO (1994). Safety and Nutritional Adequacy of Irradiated Food. World Health Organization, Geneva.

6. WHO. Wholesomeness of Irradiated Foods. Technical report Series 659, Geneva, 1981.

7. Jozsef Farkas (1990) Food Control Volume 1, Issue 4, October, Pages 223-229 
8. Gonzalez-Aguilar G, Wang CY, Buta GJ. UV-C irradiation reduces breakdown and chilling injury of peaches during cold storage. Journal of the Science of Food and Agriculture. 2004; 84: 415-422.

9. Xiong QL, Xing ZT, Feng Z, Tan Q, Bian YB. Effect of 60Co $\gamma$-irradiation on postharvest quality and selected enzyme activities of Pleurotus nebrodensis. LWT - Food Science and Technology. 2009; 42(1): 155-161.

10. Fan X, Ionizing radiation. Decontamination of Fresh and Minimally Processed Produce. Wiley-Blackwell, Oxford, 2012; pp. 576.

11. Thomas AC, Beyers M. $\gamma$ Irradiation of subtropical fruits. A comparison of the chemical changes occurring during normal ripening of mangoes and papayas with changes produced by $\gamma$ Irradiation. Journal of Agricultural and Food Chemistry. 1979; 27: 157-163.

12. Akamine EK, Moy JH. Delay in post harvest ripening and senescence of fruits, In Preservation of Food by Ionizing Radiation, Ed. Josephson ES, Peterson MS, CRC Press, Boca Raton, 1983; Vol. III, pp. 129-158.

13. Dinnocenzo M, Lajolo FM. Effect of gamma irradiation on softening changes and enzyme activities during ripening of papaya fruit. Journal of Food Biochemistry. 2001; 25: 425- 438.

14. Zhang L, Zhaoxin L, Fengxia L, Xiaomei B. Effect of gamma irradiation on quality maintaining of fresh cut lettuce. Food Control. 2006; 17(3): 225-228.

15. Cia P, Pascholati SF, Benato EA, Camili EC, Santos CA. Effects of gamma and UV-C irradiation on the postharvest control of papaya anthracnose. Postharvest Biology and Technology. 2007; 43: 366-373.

16. Olanya OM, Niemira BA, Phillips JG. Effects of gamma irradiation on the survival of Pseudomonas fluorescens inoculated on romaine lettuce and baby spinach. LWT - Food Science and Technology. 2015; 62(1): 55-61. 